\title{
Advanced Electrochemical Oxidation of Methyl Parathion at Boron-Doped Diamond Electrodes
}

\author{
Eulalio Campos-González, ${ }^{a}$ Bernardo A. Frontana-Uribe, ${ }^{b}$ Ruben Vasquez-Medrano, ${ }^{a}$ Samuel Macías- \\ Bravo, ${ }^{\mathrm{a}}$ and Jorge G. Ibanez ${ }^{\mathrm{a}, *}$ \\ a Departamento de Ingeniería y Ciencias Químicas, Universidad Iberoamericana, Prol. Reforma 880, 01219 México, D.F. \\ México.jorge.ibanez@ibero.mx \\ b Centro Conjunto de Investigación en Química Sustentable UAEM-UNAM, Toluca 50200, Estado de México. México.
}

Received February 11 $1^{\text {th }}, 2014$; Accepted April $3^{\text {rd }}, 2014$.

\begin{abstract}
Plaguicide pollution is a major problem in agricultural zones due to their intensive use to attain increased crop yields. In the present work commercial methyl parathion $(M P)$, was electrochemically degraded in a divided H-type cell equipped with two boron doped diamond electrodes, $B D D E$ and a Nafion cation exchange membrane. High removals (i.e., $>90 \%$ ) of total organic carbon, TOC and of chemical oxygen demand, $C O D$ were obtained after $180 \mathrm{~min}$ at a current density, $j$ of $5 \mathrm{~mA} / \mathrm{cm}^{2}$ with specific energy consumption, $E_{s p}$ of ca. $200 \mathrm{kWh}$ per $\mathrm{kg}$ of $C O D$ degraded. These results show that the anodic oxidation route may be an efficient alternative for $M P$ degradation in polluted waters.
\end{abstract}

Key words: Methyl parathion, BDDE, TOC, COD, current density, specific energy consumption.

\section{Introduction}

The use of substances in crops for pest control has being known since the Middle Ages, when sulfur was used for such activities [1]. During the last century the production of these substances was industrialized. In the 1930 s the first synthetic pesticides markedly improved crop yields (e.g., methyl parathion, $M P$ in 1933) and their use intensified substantially [2]. $M P$ is a very useful non systemic pesticide in food and fiber crops [3, 4]. In spite of their great usefulness many of these pesticides represent a human health threat affecting the contact chain, from those who apply them to the final consumers. In addition, due to their difficult biodegradation and easiness for lixiviation [4] pollution problems arise in surface waters, aquifers and soils. In this way, $M P$ has been detected in rivers like the Sacramento in California [5] and the Ebro in Spain [6]. MP is still used in some countries for its effectiveness but banned in others [4, 7]. A solution is now required for the disposal or elimination of these residues from the toxic and difficult-to-degrade products stored unused in commercial containers, as well as in containers of expired products. The Food and Agricultural Organization of the United Nations, FAO estimates that there are some 400,000 tons of expired pesticides in storage [5] and that the disposal cost of obsolete pesticides is of the order of USD \$3000-4500 per ton, depending on their composition [8].

Since $M P$ is a highly recalcitrant, toxic, and persistent herbicide [5] it is mandatory to develop methods to treat it so
Resumen. La contaminación por plaguicidas es uno de los mayores problemas en zonas en donde se utilizan para mejorar el rendimiento de los cultivos. En el presente trabajo se reporta la degradación de metil paratión comercial (MP) en una celda tipo $\mathrm{H}$, con dos electrodos de diamante dopado con Boro (EDDB) y una membrana Nafion de intercambio catiónico. Una alta remoción $(>90 \%)$ de carbón orgánico total (COT) y de la demanda química de oxígeno (DQO) son obtenidas después de $180 \mathrm{~min}$ a una densidad de corriente $j$ de $5 \mathrm{~mA} / \mathrm{cm}^{2}$ con un consumo especifico de energía $E_{s p}$ de $200 \mathrm{kWh}$ por kg de DQO degradado. Estos resultados muestran que la oxidación anódica puede ser una alternativa eficiente para la degradación de MP en aguas contaminadas.

Palabras clave: Metil paratión, EDDB, COT, DQO, densidad de corriente, consumo específico de energía.

that the resulting effluents be biodegradable. Typical proposed processes include adsorption [6, 7], ozonization [9], electrochemical oxidation with $\mathrm{Ti} / \mathrm{Pt} / \mathrm{Ir}$ anodes [10], photocatalytic oxidation [11], ultrasonic irradiation [12], bioremediation [13], and thermal desorption [8]. Even though adsorption can achieve high removal efficiencies, the contaminants are simply separated from their original matrix but not degraded. Advanced oxidation processes, $A O P$ (i.e., those involving the production of highly oxidizing ${ }^{\bullet} \mathrm{OH}$ radicals) can achieve high mineralization yields as is the case of the photo-Fenton [11] and electroFenton processes [14].

In the recent past the electrochemical route has become rather popular for the treatment of recalcitrant residues [15] and has proven useful in the treatment of wastewaters from olive oil production [16], residential wastes [17], lixiviates [18], tanneries [19], textile industries [20], and the like. Electrochemical methods for advanced oxidation are environmentally friendly since they do not generate new contaminants and they can treat water during the three working shifts since they are not limited to the sun assisted photo-processes [11]. Anodic oxidation at boron-doped diamond electrodes, $B D D E$ involving the production of $\bullet \mathrm{OH}$ radicals has been especially successful [21-23]. For instance, high mineralization yields have been reported (80-100\%) when using current densities of $50-2000 \mathrm{~mA} / \mathrm{cm}^{2}$ [24-27]. The electrochemical mineralization of recalcitrant organic matter at a BDD anode is possible due to the formation of the highly oxidizing hydroxyl radical 
$\left({ }^{\bullet} \mathrm{OH}, \mathrm{E}^{\circ}\left({ }^{\bullet} \mathrm{OH} / \mathrm{H}_{2} \mathrm{O}\right)=2.80 \mathrm{~V} / \mathrm{SHE}\right)[28]$ on the electrode surface at the water discharge voltages in aqueous media [29]. The general reactions that describe the mineralization of organic substances are:

$$
\begin{gathered}
\mathrm{BDD}+\mathrm{H}_{2} \mathrm{O} \leftrightarrows \mathrm{BDD}\left[\left({ }^{\bullet} \mathrm{OH}\right)\right]+\mathrm{H}^{+}+\mathrm{e}^{-} \\
\mathrm{R}_{\mathrm{n}}+x \mathrm{BDD}\left[\left(^{\bullet} \mathrm{OH}\right)\right] \rightarrow n \mathrm{CO}_{2}+y \mathrm{H}_{2} \mathrm{O}
\end{gathered}
$$

where $\mathrm{R}$ is an organic pollutant with $n$ carbon atoms.

The accepted mechanism for the oxidation of organics at BDD electrodes involves the anodic water discharge at BDD anodes that generates ${ }^{\bullet} \mathrm{OH}$ radicals adsorbed on the electrode [30]; this species can rapidly oxidize organic matter to $\mathrm{CO}_{2}$ and $\mathrm{H}_{2} \mathrm{O}$. The electrode surface is then regenerated and both intermediates are produced again after water oxidation. The amount of ${ }^{\bullet} \mathrm{OH}$ radicals adsorbed on the electrode depends on the potential used, the anode material, and the extent of the secondary reaction of oxygen production. For this reason the oxidation of organic matter effectively occurs in the vicinity of the anode.

In the present work a lab-scale electrochemical method is discussed for the treatment of $M P$ using $B D D E$ both as anode and cathode. Similar works reported to date indicate fairly high energy consumption (i.e., $1.16 \mathrm{kWh} \mathrm{g}^{-1}$ ) during $M P$ elimination [27], which represents a challenge and confirms the difficulty involved in degrading such type of pollutants.

\section{Experimental}

\section{Reagents}

Methyl parathion (O,O-diethyl O-(4-nitrophenyl) phosphorothioate, $M P$ was used either pure $\left(99.9 \%\right.$ pure, Supelco ${ }^{\circledR}$ Analytical, Bellefonte, PA) or from a commercial suspension (Foliol 70\%, Cheminova). $\mathrm{Na}_{2} \mathrm{SO}_{4}$ (Sigma Aldrich ${ }^{\circledR}, 99 \%$ pure) and $\mathrm{NaHSO}_{4}$ (Fluka Analytical, 95\% pure) were used together as supporting electrolytes. Milli-Q water $\geq 18.2 \mathrm{M} \Omega \mathrm{cm}$ was used throughout the entire experimentation protocol.

\subsection{UV-vis calibration curve for MP}

MP (Sigma-Aldrich, 99.9\% pure) was diluted as needed to prepare 1-10 ppm standard solution. Its natural solubility in water is $55-60 \mathrm{mg} / \mathrm{L}$ [2]. Due to the oily nature of the system, a methodical reproducibility was rather difficult. For this reason the mixtures were vigorously stirred for $20 \mathrm{~min}$ and sonicated in a Branson 1510 Ultrasonic Cleaner for $30 \mathrm{~min}$ to achieve complete solubilization. A qualitative UV-vis scan with a Varian Cary 50-C spectrophotometer at $4800 \mathrm{~nm} \mathrm{~min}{ }^{-1}$ revealed a peak suitable for analysis at $\lambda=277$ and a calibration curve was elaborated from the corresponding absorbance results. Concentrations higher than $10 \mathrm{ppm}$ fell outside the linear range of the corresponding Lambert - Beer plot. The regression equation obtained is $\mathrm{Abs}=0.0448 \mathrm{C}$ (in ppm), $\mathrm{R}^{2}$ $=0.9788$. See Figure 1 .

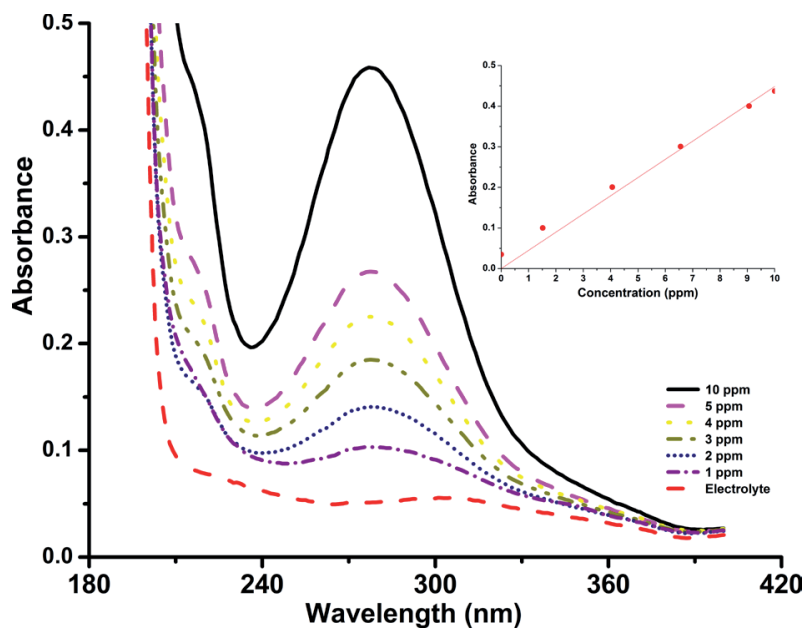

Figure 1. MP absorbance at different concentrations in sulfate buffer $\left(0.04 \mathrm{M} \mathrm{Na}_{2} \mathrm{SO}_{4} / 0.05 \mathrm{NaHSO}_{4}\right)$. Inset: Calibration curve of MP at $\lambda$ $=277 \mathrm{~nm}$ in sulfate buffer $\left(0.04 \mathrm{M} \mathrm{Na}_{2} \mathrm{SO}_{4} / 0.05 \mathrm{NaHSO}_{4}\right)$.

\subsection{Preparation of MP solutions from the commercial precursor}

The commercial insecticide Foliol (Cheminova ${ }^{\circledR}$ ) containing $450 \mathrm{~g} / \mathrm{L}$ of the active constituent methyl parathion was employed in the degradation experiments. $10 \mathrm{~g}$ of the commercial $M P$ suspension were diluted to $250 \mathrm{~mL}$ with a sulfate buffer $\left(0.04 \mathrm{M} \mathrm{Na}_{2} \mathrm{SO}_{4} / 0.05 \mathrm{NaHSO}_{4}\right)$ at $\mathrm{pH}=2.1 \pm 0.1$. No further $\mathrm{pH}$ adjustment was performed during the electrolysis experiments. This $\mathrm{pH}$ was chosen since a more complete degradation of selected organic substances has been reported at low rather than at neutral or high $\mathrm{pH}$ values [7, 29]. Application of the same solubilization protocol as described above typically produced a $500-\mathrm{ppm} M P$ solution. $100-\mathrm{ppm}$ solutions were then prepared from this stock solution by appropriate dilution.

\subsection{Electrochemical study}

A $M P$ voltammetric study was performed with the 100-ppm $M P$ standard solution described earlier using a BAS-CV 50 voltammetric analyzer in a 3-electrode cell equipped with a $B D D$ working electrode (Diachem ${ }^{\circledR}, 1 \mathrm{~cm}^{2}$ geometrical area with a $1-10 \mu \mathrm{m}$ conducting diamond layer, a $500-8000 \mathrm{ppm}$ boron concentration, and $0.1 \Omega \mathrm{cm}$ resistivity)[31]). The counter electrode was a Pt flag electrode $(3 \mathrm{~mm} \times 13 \mathrm{~mm}, 99 \%$ pure Pt, American Educational Products, product 7-501-2, Fort Collins, $\mathrm{CO}$ ) and the reference electrode was an $\mathrm{Ag} / \mathrm{AgCl} \mathrm{BAS}$ electrode.

$M P$ degradation experiments were performed in an H-type cell (Figure 2) consisting of a $250-\mathrm{mL}$ anodic compartment and a $300-\mathrm{mL}$ cathodic compartment separated by a cation exchange membrane Nafion 424 to allow the passage of protons [32]. The anodic compartment was equipped with a magnetic stirring bar that provided mass transport during the entire ex- 


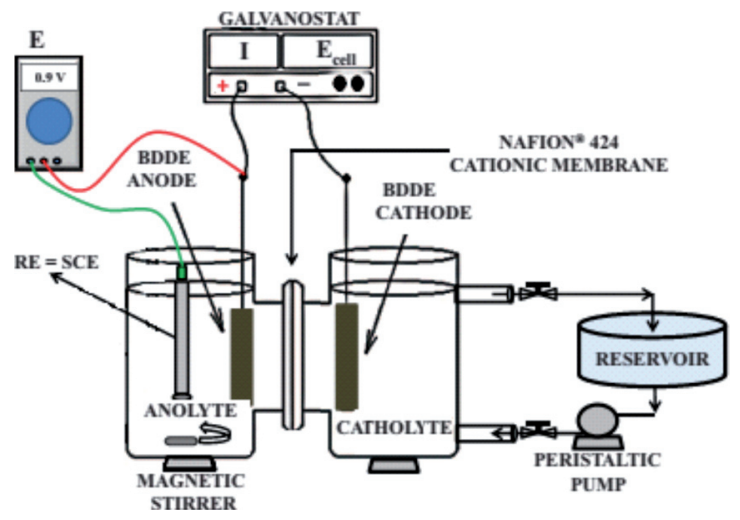

Figure 2. Electrochemical system with a divided H-type cell.

perimental procedure to speed up the electrochemical oxidation of the organic compounds with the hydroxyl radicals. Recirculation was afforded to the catholyte by a peristaltic pump (Master Flex L/S, model 77200-62) at $550 \mathrm{~mL} / \mathrm{min}$. A $40-\mathrm{cm}^{2}$ geometrical area Diachem-Condias ${ }^{\circledR} B D D$ electrode $(1-10 \mu \mathrm{m}$ conducting diamond layer, a 500-8000 ppm boron concentration, and $0.1 \Omega \mathrm{cm}$ resistivity, [31]) was inserted on each side of the cell. Prior to each experiment the anolyte was deaerated by bubbling high-purity nitrogen during $10 \mathrm{~min}$ at a rate of $10 \mathrm{~cm}^{3}$ $\mathrm{min}^{-1}$ (Infra, Chromatographic grade). Currents from 10 to 200 $\mathrm{mA}$ were passed through the cell with an AMEL 2051 potentiostat/galvanostat. The $\mathrm{pH}$ was monitored with a Conductronic ${ }^{\circledR}$ $\mathrm{pH}$-meter. Experiments were performed at room temperature (typically $22{ }^{\circ} \mathrm{C}$; its variation during the experimental runs remained within $\pm 2.5^{\circ} \mathrm{C}$ ).

\subsection{Chemical analysis}

Samples from the degradation solutions were diluted 1:10 with the buffer solution in order to have the results in the linear range reported in Figure 1, and their absorbances examined at $\lambda=$ $277 \mathrm{~nm}$. In order to follow the amount of organic compounds remaining at each time the total organic carbon, TOC and the inorganic carbon, $I C$ were monitored in $15-\mathrm{mL}$ samples at 0 , $15,30,60,90,120$ and 180 min with a Shimadzu $\mathrm{V}_{\mathrm{CPH}} \mathrm{TOC}$ analyzer. The chemical oxygen demand, $C O D$ was monitored using the standard method [33] by placing 2-mL samples in Hach $^{\circledR}$ vials containing a strongly oxidizing dichromate solution and affording a 2-h heating protocol in a Hach ${ }^{\circledR} C O D$ reactor.

The instantaneous current efficiency was calculated as the fraction of current effectively utilized for the oxidation of organic compounds as follows [34]:

$$
I C E=F V \frac{\left[(C O D)_{t}-(C O D) t+\Delta t\right]}{8 I \Delta t}
$$

where $F$ is the Faraday's constant $\left(96,487 \mathrm{C} \mathrm{mol}^{-1}\right), V$ is the volume of the solution (in L), $C O D_{t}$ and $C O D_{t+\Delta t}$ represent the chemical oxygen demand (in $\mathrm{g}_{\mathrm{O} 2} \mathrm{~L}^{-1}$ ) at times $t$ and $t+\Delta t$, respectively (in seconds), $I$ is the current passed through the system (in $A$ ), and 8 is the oxygen equivalent mass $\left(\mathrm{g} \mathrm{eq}^{-1}\right)$ $[15,34]$.

\section{Results and Discussion}

\section{Voltammetric analysis of methyl parathion on a BDDE}

Methyl parathion was voltammetrically analyzed using a BDDE in the sulfate buffer solution (Figure 3). The electrochemical window is located between -1100 and $+2200 \mathrm{mV}$. The small peak observed at the foot of the anodic barrier (inset a) corresponds to the oxidative degradation of electrode impurities $[35,36]$. The cathodic system (inset b) observed at ca. -750 $\mathrm{mV}$ corresponds to the nitroaromatic group reduction, and the other major anodic and cathodic peaks correspond to the hydroxylamine-nitrosoaromatic system [37]. The difficulty for the oxidative degradation of $M P$ is evidenced by the lack of an anodic signal (inset c) since the sole response observed was water electrolysis. Therefore the $M P$ oxidation is not direct and the electrochemical generation of ${ }^{\bullet} \mathrm{OH}$ radicals at the $B D D E$ is necessary to accomplish this degradation as described below.

\section{Electrochemical degradation of methyl parathion}

In order to evaluate the effect of current density on the degradation of $M P$, its concentration was spectrophotometrically monitored as a function of time at different applied current densities, $j: 0.25,0.625,1.25,2.5$ and $5 \mathrm{~mA} \mathrm{~cm}^{-2}$. Such a current density range was selected in order to maintain low energy consumption [17, 24-27]. It is well known that low current densities do not completely destroy all the organic species, but they should suffice to destroy $M P$ which is the objective of the present work.

The MP concentrations in the electrolysis solutions were determined using the calibration curve depicted in Figure 1

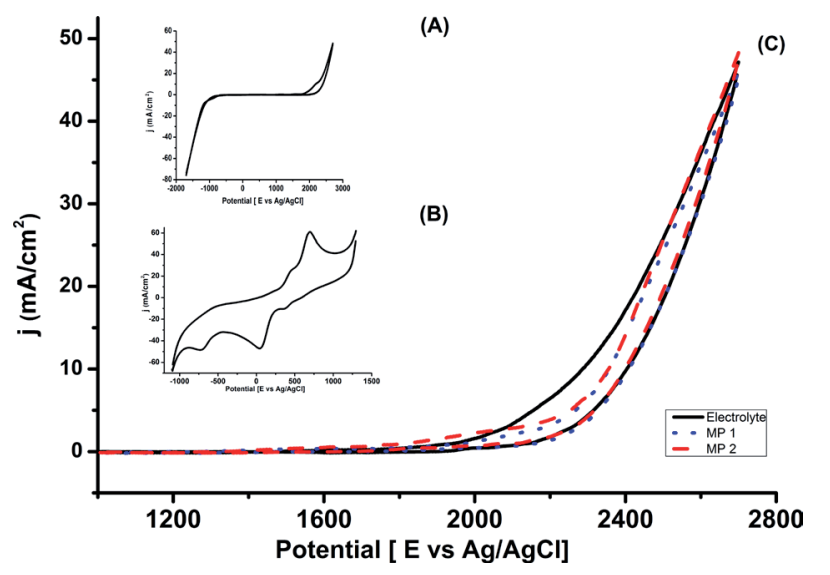

Figure 3. Cyclic voltammograms of $\mathrm{MP}$ at a $\mathrm{BDDE}$ in the sulfate buffer solution $\left(0.04 \mathrm{M} \mathrm{Na}_{2} \mathrm{SO}_{4} / 0.05 \mathrm{NaHSO}_{4}\right), \mathrm{v}=30 \mathrm{mV} / \mathrm{s}$. a) Supporting electrolyte, b) cathodic behavior, and c) anodic behavior. 
after a 1:10 dilution as described above. Figures 4 and 5 show the UV-vis spectra of the $M P$ solutions for 0.25 and $5 \mathrm{~mA} \mathrm{~cm}^{-2}$, respectively. The peak at $277 \mathrm{~nm}$ is associated with the conjugate double bonds in $M P$ [27] and thus its intensity decrease mirrors the $M P$ concentration.

Figure 6 shows the normalized $M P$ concentration variation as a function of time at different current densities. As the current density increases the disappearance of the pesticide becomes faster. At $5 \mathrm{~mA} / \mathrm{cm}^{2}$ the $M P$ concentration decreases from $100 \mathrm{ppm}$ down to ca. $10 \mathrm{ppm}$ in merely one hour of electrolysis; after that, mass transport limitations are observed.

The reactions occurring in the anodic compartment are generalized in equations 1 and 2, while the simultaneous oxygen production during water electrolysis occurs as well [21].

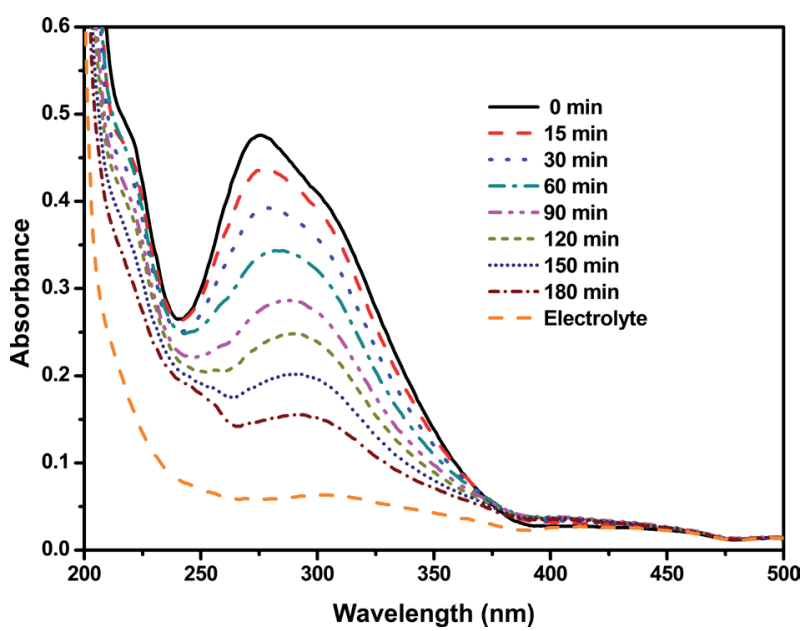

Figure 4. UV-Vis monitoring of the electrochemical oxidation of a 100 -ppm MP solution at $j=0.25 \mathrm{~mA} \mathrm{~cm}^{-2}$.

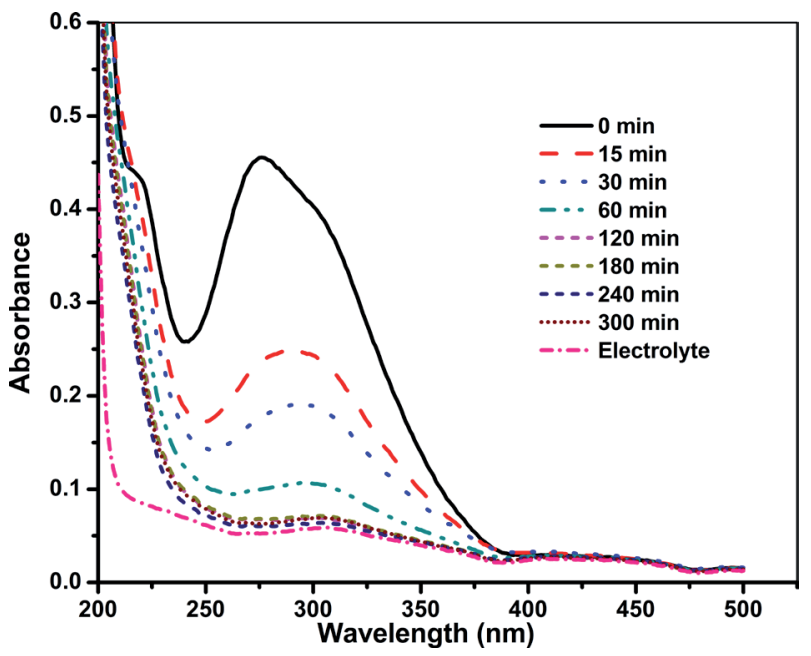

Figure 5. UV-Vis monitoring of the electrochemical oxidation of a 100 -ppm MP solution at $j=5 \mathrm{~mA} \mathrm{~cm}^{-2}$.
Although $M P$ and its degradation products are oxidized in the anodic compartment by direct reaction with the hydroxyl radicals generated from water oxidation at $B D D$ [34], the $M P$ disappearance does not necessarily reflect its complete mineralization. Furthermore, it is well known that intermediates produced during the degradation of some pollutants often are even more dangerous than the parent compounds themselves. Therefore the monitoring of the total amount of organic carbon, TOC would render a more realistic indicator of the disappearance of all the organic compounds from the target solution. Figure 7 shows the percent $T O C$ removal as a function of time for all the current densities described earlier. It can be observed that the higher the current density, the higher and faster the TOC removal (up to ca. 95\%).

In order to better understand the fate of the degradation products, the inorganic carbon, $I C$ was also monitored in each solution. This gives a quantitative indication of the amount of carbon that became dissolved in the solution as carbonate [38]. Figure 8 shows the percent organic carbon removal as well as the amount of inorganic carbon found in the solution as a function of time for $j=0.25 \mathrm{~mA} \mathrm{~cm}^{-2}$. Albeit slowly (since almost no mineralization occurs in the first half of the reaction), the system behaves normally in the sense that $T O C$ decreases with time while $I C$ increases at this $j$. On the other hand, while TOC also decreases with time at $j=5 \mathrm{~mA} \mathrm{~cm} \mathrm{~cm}^{-2}$ (see Figure 9), the $I C$ peaks rapidly at ca. $2 \mathrm{~h}$. This reflects a faster mineralization (i.e., a high $T O C$ removal, ca. $70 \%$ that produces a high IC) after which the parasitic solvent decomposition starts predominating.

Since the chemical oxygen demand, $C O D$ is an important parameter in the water treatment field this was monitored as a function of time at the same current densities described earlier (see Figure 10). In agreement with the TOC experiments, the highest $j$ (i.e., $5 \mathrm{~mA} \mathrm{~cm}^{-2}$ ) renders the highest $C O D$ removal,

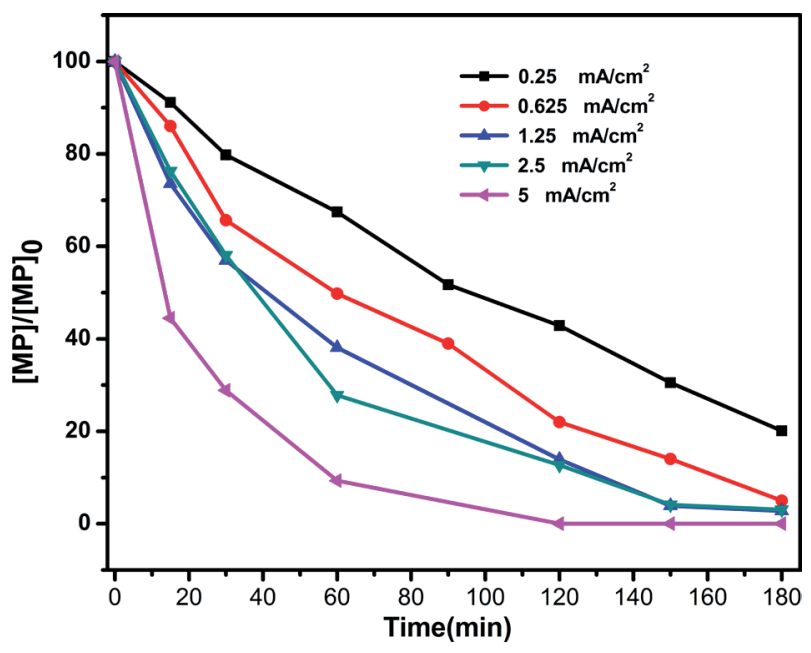

Figure 6. Normalized MP concentration change as a function of time at different current densities. MP concentration in the starting solutions $=100 \mathrm{ppm}$. 


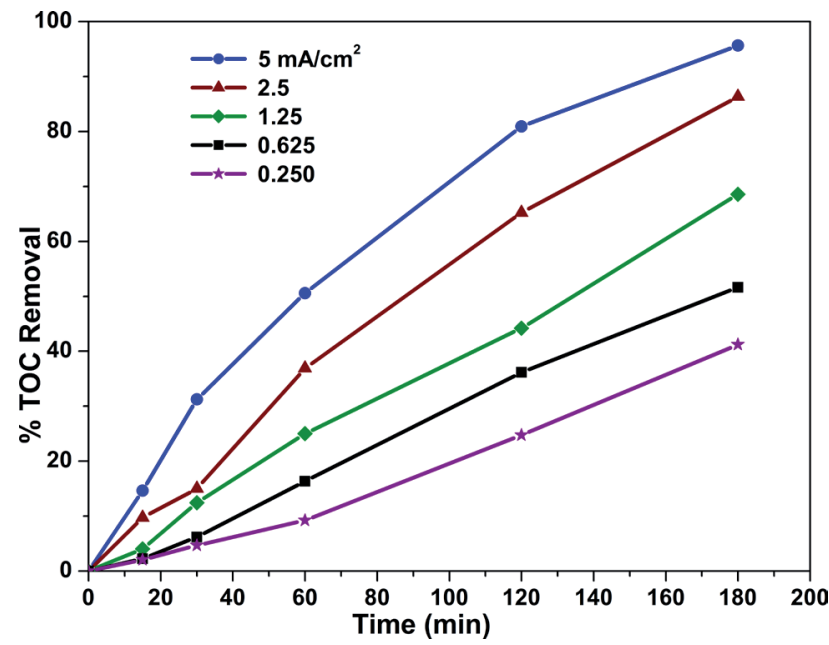

Figure 7. TOC removal as a function of time and current density.

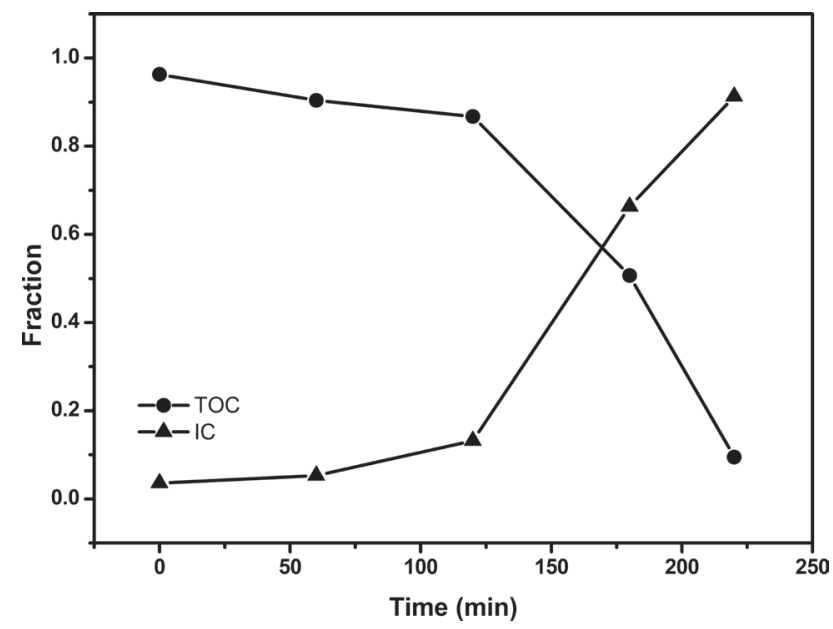

Figure 8. Normalized TOC and IC evolution during the electrochemical oxidation of commercial MP at $j=0.25 \mathrm{~mA} \mathrm{~cm}^{-2}$.

reaching $>90 \%$ after $180 \mathrm{~min}$. The monitoring of $C O D$ values shows that the intermediates decrease with time, which points at a total mineralization of the majority of organic matter present.

The instantaneous current efficiency, ICE is defined as the portion of the current directly used for the oxidation of organic compounds [39] and was evaluated for the treatment of the 100ppm $M P$ solution as a function of time and of current density (see Figure 11). The \% ICE is clearly better for lower $j$ values, which translates into a better use of current because ${ }^{\circ} \mathrm{OH}$ are preferentially produced thus limiting oxygen evolution. Higher $j$ values promote faster degradation rates accompanied by the concomitant higher production of oxygen and an ICE decrease. This was to be expected because the origin of the ${ }^{\bullet} \mathrm{OH}$ radicals is the oxidation of water molecules at the $B D D E$.

For our experimental conditions limited amounts of peroxodisulfate might be generated; nonetheless sulfate concentra-

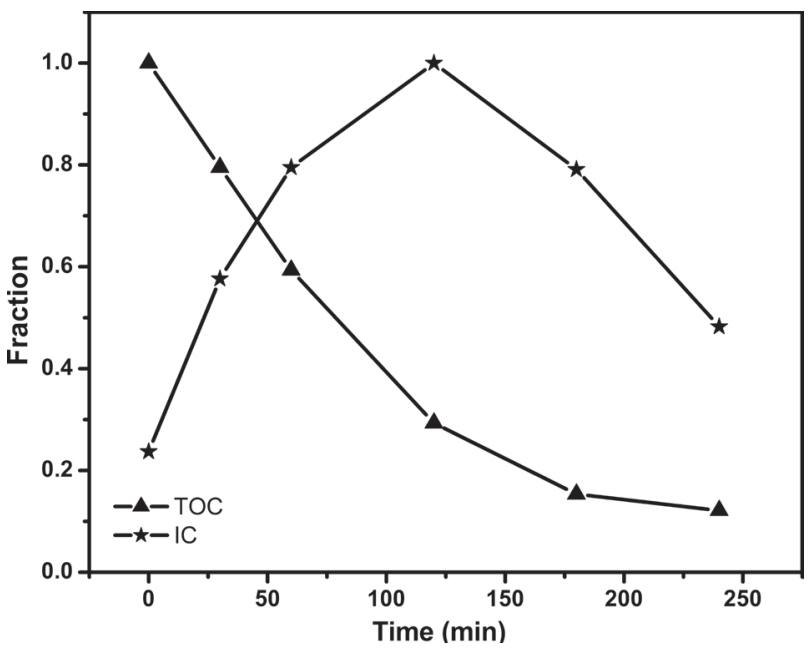

Figure 9. Normalized TOC and IC evolution during the electrochemical oxidation of commercial MP at $j=5 \mathrm{~mA} \mathrm{~cm}^{-2}$.

tions should be higher than $2 \mathrm{M}$ for sulfate oxidation to become important [32, 40, 41].

\section{Energy consumption, EC during electrolysis}

This is a crucial issue for the determination of the effectiveness of the process. The specific energy consumption, $E_{s p}$ is a key parameter to understand the scalability of water treatment systems for high influent volumes as well as the global efficiency of the oxidation process. It relates the energy consumed per $\mathrm{kg}$ of $\mathrm{COD}\left(\mathrm{kWh} \mathrm{kg}_{\mathrm{COD}^{-1}}\right)$ as follows [39]:

$$
E_{s p}=\frac{1}{3600} \frac{F}{8} \frac{V_{C}}{\bar{\eta}}
$$

where $V_{C}=$ cell potential $(V), \bar{\eta}=$ average current efficiency, and 8 is the mass equivalent of oxygen. $\bar{\eta}$ can be calculated by integrating the ICE over the entire experimental time, $\tau$ :

$$
\bar{\eta}=\frac{\int_{0}^{\tau} I C E(t) d t}{\tau}
$$

Figure 12 shows the variation of $E_{s p}$ and $\% C O D$ removal with $j$. Higher $j$ values yield higher $\% C O D$ removals albeit at the expense of higher $E_{s p}$ requirements.

Lastly, power consumption $(P$, in $\mathrm{kWh}$ ) during the electrolytic degradation is determined as follows [42]:

$$
P=\frac{E_{\text {cell }} \cdot I \cdot t}{1000}
$$

where $E_{\text {cell }}$ is cell potential $(V), I$ is applied current $(A)$ and $t$ is electrolysis time $(h)$. The value that recounts energy consumption per gram of $C O T$ removed is given by:

$$
E C=\frac{P}{m}
$$

where $m$ is the mass of $T O C$ removed $(g)$. See Figure 13. 


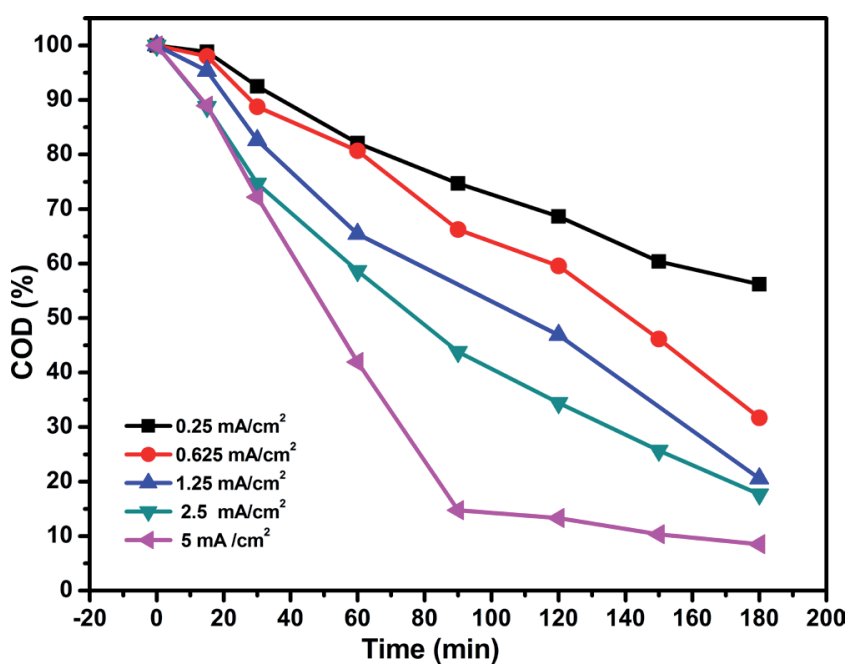

Figure 10. Effect of current density on COD removal.

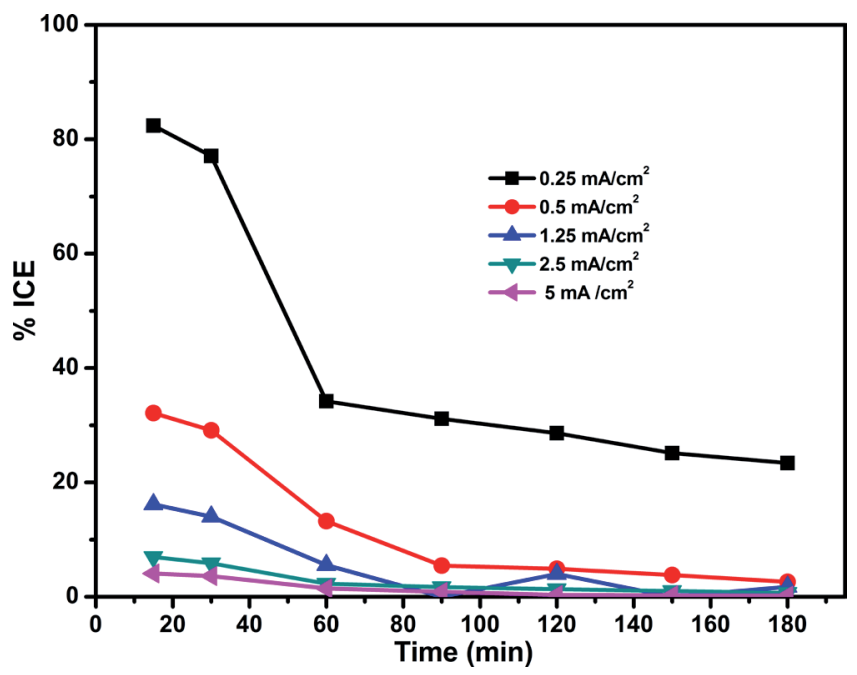

Figure 11. ICE variation during MP oxidation.

The highest current density used in the present work (i.e., $5 \mathrm{~mA} \mathrm{~cm}$ ) is capable of mineralizing $97 \%$ of the TOC. In contrast, that reported elsewhere for MP [27] at the same $j$ yields only $20 \%$ mineralization. This result supports the prospects of pilot plant escalation.

\section{Conclusions}

This work evidences that commercial $M P$ can be efficiently mineralized in acidic aqueous solution at a $B D D E$ with high $T O C$ and $C O D$ removals, together with a specific energy consumption of only $12 \%$ compared to earlier reports [27]. $M P$ removals range from $45 \%$ at $0.25 \mathrm{~mA} / \mathrm{cm}^{2}$ up to $93 \%$ at 5 $\mathrm{mA} / \mathrm{cm}^{2}$. Overall, this is a promising option for the treatment of water polluted with $M P$.

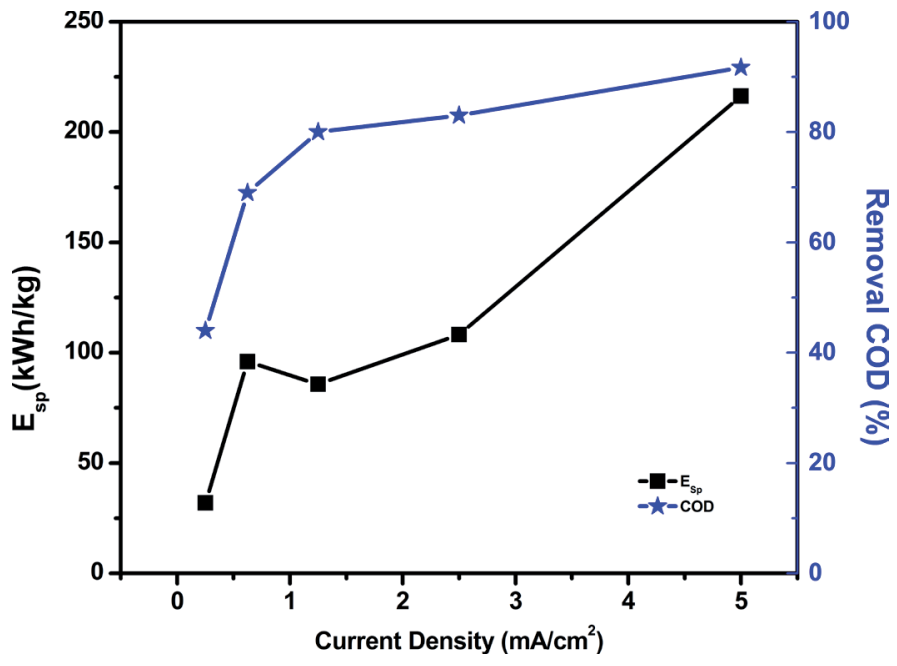

Figure 12. Esp = Specific energy consumption, $\mathrm{COD}=$ chemical oxygen demand.

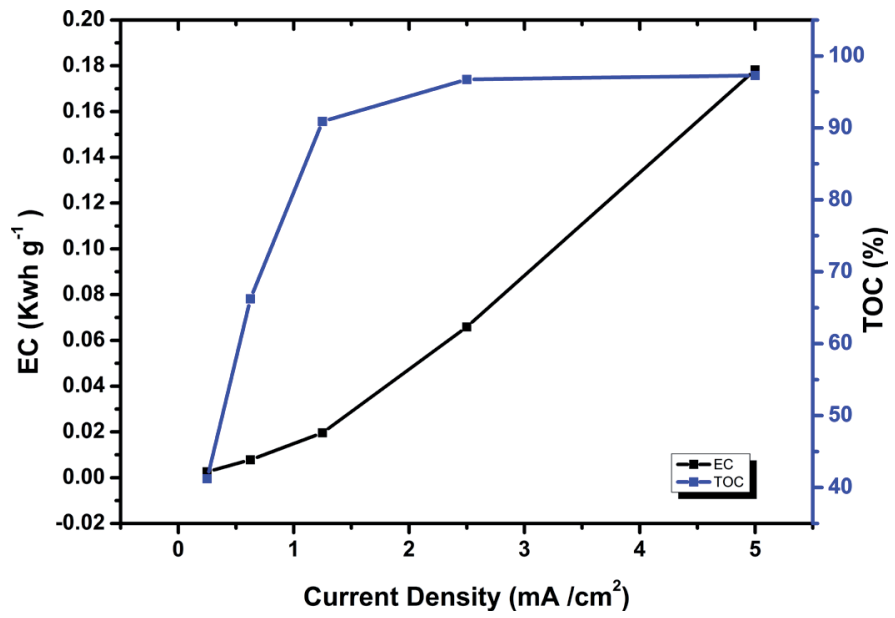

Figure 13. Ec $=$ Energy consumption, $\mathrm{TOC}=$ Total organic carbon .

\section{Acknowledgements}

We acknowledge financial support from CONACYT in the form of a scholarship to Eulalio Campos as well as from Universidad Iberoamericana (Project 0053). Experimental assistance was provided by Ana Paula Gartland-Masana and Mario Palazuelos-Argaiz. Helpful insights from Patricio EspinosaMontero are also gratefully acknowledged.

\section{References}

1. García-Calvo, E.; Fernández Alba-Rodríguez, A.; Rodríguez, R. Technical alternatives for the elimination of plaguicides in the environment. (In Spanish). IV Seminario Internacional sobre Residuos de Plaguicidas, Almería, Spain. 1996. http://dialnet.unirioja. es/servlet/articulo?codigo=1039293, accessed in January, 2014.

2. International Program on Chemical Safety, Environmental Health Criteria 145 Methyl Parathion, 09-20-12, http://www.inchem.org/ documents/ehc/ehc/ehc145.htm, accessed in January, 2014. 
3. González-Arias, C. A.; Robledo-Marenco, M. L.; Medina-Díaz, I. M.; Velázquez-Fernández, J. B.; Girón-Pérez, M. I.; QuintanillaVega, B.; Ostrosky-Wegman, P.; Pérez-Herrera, N. E.; Rojas-Garcia, A. E. Rev. Int. Contam. Ambient. 2010, 26, 221-228.

4. USEPA (U.S. Environmental Protection Agency). Interim reregistration eligibility decision for methyl parathion: U.S. Environmental Protection Agency, Prevention, Pesticides and Toxic Substances, EPA 738-R-01-007 February 2002. See also: Finalization of Interim Reregistration Eligibility Decisions (IREDs) and Interim Tolerance Reassessment and Risk Management Decisions (TREDs) for the Organophosphate Pesticides, and Completion of the Tolerance Reassessment and Reregistration Eligibility Process for the Organophosphate Pesticides, July 31, 2006, http://www. epa.gov/oppsrrd1/REDs/methylparathion_ired.pdf, accessed in January, 2014.

5. Schimmel, S. C.; Garnas, R. L.; Patrick Jr., J. M.; Moore, J. C. J. Agric. Food Chem. 1983, 31, 104-113.

6. Ormad, M. P.; Miguel, N.; Claver, A.; Matesanz, J. M.; Ovelleiro, J. L. Chemosphere 2008, 71, 97-106.

7. Akhtar, M.; Hasany, S. M.; Bhanger, M. I.; Iqbal, S. Chemosphere 2007, 66, 1829-1838.

8. FAO Pesticide Disposal Series. Baseline study on the problem of obsolete pesticide stocks. Rome, Italy. 2000.

9. Wu, J. G.; Luan, T. G.; Lan, C. Y.; Lo, W. H.; Chan G. Y. S. J. Food Eng. 2007, 79, 803-809.

10. Muff, J.; Andersen C. D.; Erichsen, R.; SØgaard, E. G. Electrochemical oxidation of pesticides polluted drainage water in its natural matrix, EAAOP-2: $2^{\text {nd }}$ European conference on environmental applications of advanced oxidation processes. Nicosia, Cyprus. 2009.

11. Pignatello, J. J.; Sun Y. Water Res. 1995, 28, 1837-1844.

12. Kotronarou, A.; Mills, G.; Hoffmann, R. M. Environ. Sci. Technol. 1992, 26, 1460-1462.

13. Yang, J.; Liu, R.; Jiang, H.; Yang, Y.; Qiao, C. Appl. Microbiol. Biot. 2012, 95, 1625-1632.

14. Diagne, M.; Oturan, N.; Oturan, M. A. Chemosphere 2007, 66, 841-848.

15. Rajeshwar, K.; Ibanez, J. G. Environmental Electrochemistry: Fundamentals and applications in pollution abatement, Academic Press, San Diego, 1997.

16. Israilides, C. J.; Vlyssides, A. G.; Mourafeti, V. N.; Karvouni, G. Bioresource Technol. 1997, 61, 163-170.

17. Della Monica, M.; Agostiano, A.; Ceglie, A. J. Appl. Electrochem. 1980, 10, 527-533.

18. Deng, Y.; Englehardt, D. J. Waste Manage. 2007, 27, 380388.

19. Costa, C. R.; Montilla, F.; Morallón, E.; Olivi, P. J. Hazard. Mater. 2010, 180, 429-435.

20. Körbahti, K. B.; Tanyolaç, A. J. Hazard. Mater. 2009, 170, 771778.
21. Cieciwa, A.; Fóti, G.; Comninellis, Ch. Electrochemistry for the environment, Springer, New York, 2010.

22. Martínez-Huitle, C.; Brillas, E. Appl. Cat. B: Environ. 2009, 87, 105-145

23. Panizza, M.; Martinez-Huitle, C. Chemosphere 2013, 90, 14551460.

24. Brillas, E.; Boyce, B.; Sires, I.; Garrido, J. A.; Rodriguez, R. M.; Arias, C.; Cabot, P.; Comninellis, Ch. Electrochim. Acta 2004, 49, 4487-4496.

25. Sires, I.; Cabot, P. L.; Centellas, F.; Garrido, J. A.; Rodriguez, R. M.; Arias, C.; Brillas, E. Electrochim. Acta 2006, 52, 75-85.

26. Boye, B.; Brillas, E.; Marselli, B.; Comninellis, Ch.; Farnia, G.; Sandona, G. Electrochim. Acta 2006, 51, 2872-2880.

27. Alves, S. A.; Ferreira, T. C. R.; Migliorini, F. L.; Baldan, M.; Lanza, M. R. V. J. Electroanal. Chem. 2013, 702, 1-7.

28. Brillas, E.; Sirés, I.; Oturan, M. A. Chem. Rev. 2009, 109, 65706631.

29. Iniesta, J.; Michaud, P. A.; Cerisola, G.; Aldaz, A.; Comninellis, C. Electrochim. Acta 2001, 46, 3573-3578.

30. Fóti, G. ; Gandini, D.; Comninellis, C. ; Perret, A.; Haenni, W. Electrochem. Solid-State Lett. 1999, 2, 228-230.

31. Tröster, I.; Fryda, M.; Herrmann, D.; Schäfer, L.; Hänni, W.; Perret, A.; Blaschke, M.; Kraft, A.; Stadelmann, M. Diam. Relat. Mater. 2002, 11, 640-645.

32. Espinoza-Montero, P. J.; Vasquez- Medrano, R.; Ibanez, J. G.; Frontana, B. A. J. Electrochem. Soc. 2013, 160, G3171-G3177.

33. Eaton, A. D.; Clesceri, L. S.; Greenberg, A. E.; Franson, M. A. H. APHA, Standard Methods for the Examination of Water and Wastewater, 20th ed., American Public Health Association, Washington, DC, 1999.

34. Panizza, M.; Brillas, E.; Comninellis, C. J. Environ. Eng. Manag. 2008, 18, 139-153.

35. Chaplin, B. P.; Hubler, D. K.; Farrell, J. Electrochim. Acta 2013, 89, 122-131.

36. Granger, M. C.; Witek, M.; Xu, J.; Wang, J.; Hupert, M.; Hanks, A.; Koppang, M. D.; Butler, J. E.; Lucazeau, G.; Mermoux, M.; Strojek, J. W.; Swain, G. M. Anal. Chem. 2000, 72, 3793-3804.

37. Tcheumi, H. L.; Tonle, K. I.; Ngameni, E.; Walcarius, A. Talanta 2010, 81, 972-979.

38. Vlyssides, A.; Barampouti, E. M.; Mai, S. Environ. Sci. Technol. 2004, 38, 6125-6131.

39. Panizza, M.; Michaud, A. P.; Cerisola, G.; Comninellis, Ch. Electrochem. Commun. 2001, 3, 336-339.

40. Serrano, K.; Michaud, P. A.; Comninellis, C.; Savall, A. Electrochim. Acta 2002, 48, 431-436.

41. Michaud, P. A.; Mahe, E.; Haenni,W.; Perret, A.; Comninellis, C. Electrochem. Solid-State Lett. 2000, 3, 77-79.

42. Alves, S. A.; Ferreira, T .C. R. ; Sabatini, N. S.; Trientini, A. C. A.; Migliorini, F. L.; Baldan, M. R.; Ferreira, N. G.; Lanza, M. R. V. Chemosphere 2012, 88, 155-160. 